Chicago-Kent College of Law

Scholarly Commons @ IIT Chicago-Kent College of Law

All Faculty Scholarship

Faculty Scholarship

February 2003

\title{
Cultural Property and the Limitations of Preservation
}

Sarah K. Harding

IIT Chicago-Kent College of Law, sharding@kentlaw.iit.edu

Follow this and additional works at: https://scholarship.kentlaw.iit.edu/fac_schol

Part of the Property Law and Real Estate Commons

\section{Recommended Citation}

Sarah K. Harding, Cultural Property and the Limitations of Preservation, 25 Law \& Pol'y 17 (2003).

Available at: https://scholarship.kentlaw.iit.edu/fac_schol/266

This Article is brought to you for free and open access by the Faculty Scholarship at Scholarly Commons @ IIT Chicago-Kent College of Law. It has been accepted for inclusion in All Faculty Scholarship by an authorized administrator of Scholarly Commons @ IIT Chicago-Kent College of Law. For more information, please contact jwenger@kentlaw.iit.edu, ebarney@kentlaw.iit.edu. 


\title{
Cultural Property and the Limitations of Preservation
}

\author{
SARAH HARDING*
}

\begin{abstract}
Many of the things and places we identify as "cultural property" are in every sense public: they reflect collective experiences in their creation, formal dedication, and the ongoing re-inscription of their meaning. Yet cultural property is a large and protean category of things and places, encompassing far more than public memorials. The significance of much (if not most) cultural property originates not in the public realm but in the open-ended possibilities of personal engagement that enable a "wide range of interpretive distinctions." This paper explores how this vital interpretive process is mediated by public recognition and preservation of cultural property through a growing body of cultural preservation laws.
\end{abstract}

\section{INTRODUCTION}

Many of the things and places we identify as "cultural property" are in every sense public: they are a product of and reflect our collective experiences in their creation, in their formal dedication, and in the ongoing reinscription of their meaning. Widely recognizable landmarks and objects such as the Statue of Liberty, the Declaration of Independence, and the Vietnam Memorial fit well into this category. These and other similar items of cultural property are the products of broadly shared cultural meanings and, as such, readily assume the status of cultural icons. Yet cultural property, even in the most conventional sense, is a large and protean category of things and places, encompassing far more than public memorials and icons. It embraces significant

\footnotetext{
* Associate Professor, Chicago-Kent College of Law; Visiting Research Fellow (2002-03), Research School of Social Sciences, Australian National University. Previous versions of this paper were presented at the 2002 joint annual meetings of the Law and Society Association and Canadian Law and Society Association and the Law, Culture and the Humanities Workshop 2002. I am also greatly indebted to Ujjval Vyas for urging me to organize the interdisciplinary Cultural Preservation discussion that generated the ideas behind this paper and for our many lively debates on this topic.

Address correspondence to Sarah Harding, Chicago-Kent College of Law, 565 West Adams Street, Chicago, IL 60661. Telephone: (312) 906-5227; e-mail: sharding@kentlaw.edu.

LAW \& POLICY, Vol. 25, No. 1, January 2003

ISSN 0265-8240

(C) Blackwell Publishing Ltd. 2003, 9600 Garsington Road, Oxford OX4 2DQ, UK, and 350 Main Street, Malden, MA 02148, USA.
} 
literary and artistic creations, antiquities, architectural jewels, religious objects, historical oddities, memorabilia, and the unique and often compelling creations of indigenous peoples. The concept of cultural heritage extends this definition even further to embrace intangibles such as folklore, scientific knowledge, and sacred rituals (Daes 1999:24; Harding 1999:297-304).

As the breadth of this terrain suggests, the significance of much (if not most) cultural property and heritage originates not in the public realm but in personal experiences, everyday life, and local contexts. Although we may easily recognize the personal genesis of the creation and interpretation of canonical paintings and literary texts, likewise something large and public, for example the Sydney Opera House, becomes meaningful through personal as well as collective experiences. The significance of cultural property is a product of multiple interactions. Put another way, it is the open-ended possibilities of personal engagement that establish and enable the "wide range of interpretive distinctions" of cultural property (Robinson 2001:10).

This paper explores how this vital interpretive process is mediated by public recognition and preservation through a growing body of cultural preservation laws. Cultural preservation laws take on many forms: the protection of the heritage of indigenous peoples (e.g., Native American Graves Protection and Repatriation Act of 1990 [NAGPRA]: $\$ 3001-3013$; Aboriginal and Torres Strait Islanders Heritage Protection Act of 1984); private heritage or preservation easements (e.g. ALI-ABA 2001); import and export regulations (e.g., Pre-Columbian Monumental and Architectural Sculpture and Murals Statute 1972; Convention on Cultural Property Implementation Act 1987); ${ }^{\prime}$ international agreements (e.g., Convention for the Protection of Cultural Property in the Event of Armed Conflict; UNIDROIT Convention on Stolen or Illegally Exported Cultural Objects); and local landmark preservation ordinances (e.g., Chicago, Il, Municipal Code 1987:\$2-120-620). These laws play a significant role in determining questions of ownership (e.g., NAGPRA) ${ }^{2}$ as well as the scope of ownership interests, ${ }^{3}$ in the name of "culture."

The common goal of these preservation laws is to keep some remnants of culture intact - but do they succeed? What is the impact of preservation legislation on the personal foundations of our collective cultural sensibility? Do such laws lull us into believing that "culture" exists only in things and places with a recognized pedigree, or that the cultural authenticity of a given thing or place is indisputably clear and objective? Ultimately do such laws lead us to ignore lived experience, and the choices that constitute that experience, as crucial to our interpretations of cultural property?

While this paper takes on a critical tone it is neither intended, nor should it be interpreted, as an outright rejection of the increasing body of cultural preservation laws. I have written in other places about the advantages of such laws (see generally, Harding 1999). My intent here is to explore the limitations of these laws, how they may obscure and limit the important cultural choices we make. In short, cultural preservation laws require us to translate the 
meaning of objects and places into a set of defined public standards and in doing so we invariably lose some nuanced sense of the personal choices that, in a very real sense, constitute culture.

\section{TWO CASES STUDIES}

The two examples that follow, one from a paper by anthropologist Michael Harkin (2001), the other from architect Sidney Robinson (2001), come from a small conference at Chicago-Kent College of Law in September 2001. Both of these papers focused on cultural preservation issues and concerns in the narrow area of the expertise of their authors. Both highlighted a tension between "culture" and the individual, not necessarily between competing cultures. An important idea that surfaced from that discussion and these papers was the loss of a vital personal element in our desire to protect and preserve things through a host of cultural preservation laws. These papers provide an interesting starting point not only because they raise a common theme but that they do so in two very different contexts.

\section{A. THE MASKS AND CEREMONIAL OBJECTS OF THE KWAKIUTL}

Michael Harkin begins his discussion with a telling of the now familiar "eradicationist project" on the Northwest coast in which missionaries, anthropologists, and a hungry art market converged to eradicate Northwest Coast Indian culture. The vast funneling of objects to Western museums and private collectors that occurred in this project reached its pinnacle in 1921 in a police raid on a potlatch hosted by Chief Dan Cranmer. The raid was pursuant to a law passed by the Canadian Parliament in 1885 that outlawed the potlatch, an elaborate gift-giving ritual practiced by most of the Northwest Coast cultures (Statutes of Canada 1884; see generally, Jonaitis 1991). Given that most of the artistic and expressive culture of these communities was associated with the potlach, the law in effect outlawed most visible forms of cultural representation. The raid resulted in forty-five successful prosecutions but those arrested accepted suspended sentences in exchange for masks and ceremonial objects. In total, seven hundred fifty objects were confiscated. These objects "were to form the basis for ethnological collections at museums in Ottawa, Toronto, and New York" (Harkin 2001:2; see generally, Cole 1985; Jonaitis 1991). ${ }^{4}$

The last two decades have ushered in an era of repatriation. Either through ad hoc negotiations, an approach more common in Canada (Harkin 2001:8; Canadian Museum of Civilization 2001-2002), ${ }^{5}$ or repatriation legislation, specifically NAGPRA, many important cultural objects have been returned. Most of the potlatch collection was returned by the Canadian Museum of Civilization (formerly the National Museum of Man) in 1979 (Harkin 2001:8). 
If we look closely at NAGPRA, the primary legislative mechanism for repatriations from federally funded institutions in the United States, it defines cultural patrimony as objects having "ongoing historical, traditional or cultural importance, central to the Native American group or culture itself" and those which were "considered inalienable by such Native American group at the time the object was separated from such group" (NAGPRA 1990: $33001[3 D]$; see generally, Harding 1997). The two conceptual anchors for this definition are cultural significance and collective ownership. The conflict that emerges in the context of the Northwest Coast cultures is that private, not collective, ownership was standard with respect to ceremonial objects. Private ownership of land and goods was well established in this area but "the most private sort of private property were the ceremonial objects ... that have come to be seen as prime examples of cultural property" (Harkin 2001:5).

It is important to note that these objects were personal in more ways than ownership. They were created to reflect both the spirit world and the personal features and characteristics of the individual owner, thus serving as an "aesthetic unification between wearer and the being." Many ceremonial objects had "explicit or implied life cycles" mimicking human life and death. For example, masks (see fig. A), were thought to have transcendental qualities, transforming individual owners into "spirit beings" and the "cosmological state

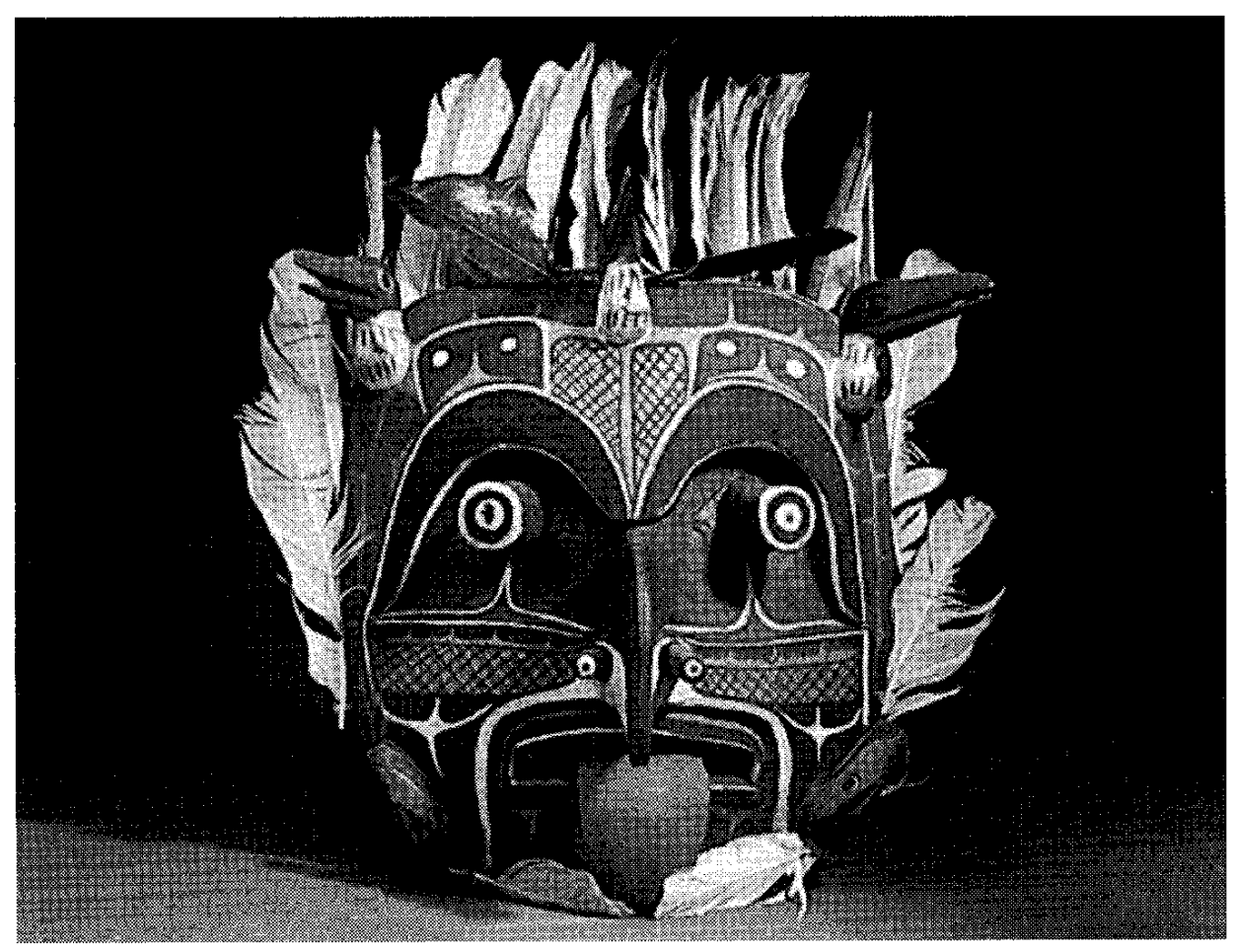

Fig. A: Xwe Xwe Mask

(C) Blackwell Publishing Ltd. 2003 
of affairs present at creation" (Harkin 2001:11-12). It is no surprise given this richness in personal significance that masks were often destroyed at the death of their owners, thus harmoniously sending both off to another life.

Despite the intensely personal nature of these ceremonial objects, they have been, and continue to be, repatriated as cultural objects belonging to the tribe as a whole. The conflict between the personal and cultural significance of these objects is more than academic. The repatriation of ceremonial objects has been supported and encouraged by younger members of the tribes "who wish to reconstruct an idealized vision of native culture as a communitarian utopia" (Harkin 2001:5). In the Northwest Coast context, this has involved the creation and establishment of museums or cultural institutions to display the objects (see Clifford 1997). ${ }^{6}$ Older members of the tribes in question are often opposed to this shared understanding and significance, not to mention public display of these intensely personal objects. Harkin concludes "the acceptance of repatriated objects as cultural property, that is constituting part of an inalienable, communal heritage, is a radical innovation" (2001:7). This innovation extends not only to the recasting of personal objects as cultural icons but to the creation of wholly artificial ethnicities where before existed only families or clan groups. This is most clearly captured in the debate over the creation of a "Tlingit National Anthem" - a striving for nationhood - "which traditionalists abhor as, paradoxically, very un-Tlingit." Harkin goes on to comment that the advocates of a national anthem are the same individuals who are behind the repatriation of "cultural patrimony" (ibid.:8).

Thus the repatriation of cultural objects to the Northwest Coast cultures poses an interesting problem. On the one hand, repatriation would seem to be the right thing to do, at the very least as an act of compensation for years of cultural oppression and misappropriation. On the other hand, repatriation itself, can be understood as yet another aspect of Western domination in that the meaning and significance of repatriated objects is at least partially influenced by "the representational hegemony of museums" and as such is "yet another instance of cultural domination in a long history of it" (ibid.:17-8).

\section{B. THE FORD HOUSE}

Sidney Robinson's house, known as the Ford House provides another example of the potential conflicts in the policies of preservation. In one sense it is just a house, a rather small house in suburban Chicago. As a residential property, its function and meaning are obvious. We can draw on our own familiar range of emotional and intellectual encounters with living space to understand its personal meanings to its owner, Robinson. However, the Ford House (see figure B) is not your typical suburban home. It is in almost every aspect unusual. It was designed by Bruce Goff, a well-known and written about architect (see generally, Saliga \& Woolever 1997; DeLong 1988). ${ }^{7}$ 


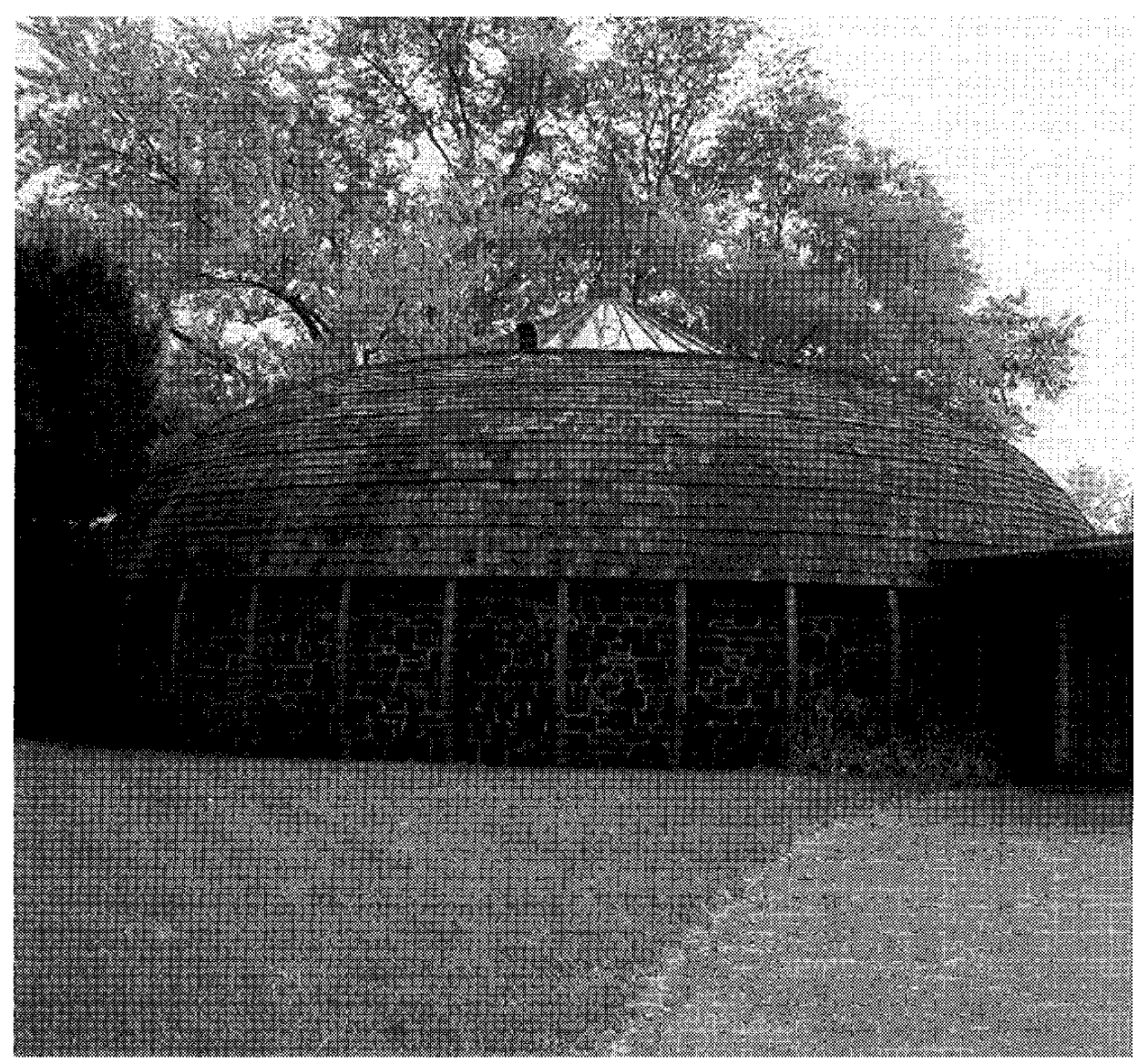

Fig. B: The Ford House; architect Bruce Goff

According to all the hallmarks of significance, the Ford House is a landmark. People from all over the world have called and knocked on Robinson's door to arrange a viewing - no less than one hundred twenty-five one Sunday afternoon - and it is eye catching, built in the manner of a Quonset Hut (see figure B). These seem to be some of the key reasons why the Landmarks Preservation Council of Illinois is interested in the house and would like to prevent subsequent owners from altering it through a preservation easement (Robinson 2001:1). ${ }^{8}$ The Council has effectively used this approach since the mid-1970s to preserve property remaining in private hands. It acquires properties through purchase or donation and then resells them to private owners with an easement requiring the owners to preserve and maintain the critical historic features of the property in perpetuity. The council holds such easements on more than fifty properties throughout Illinois. ${ }^{9}$ Not unlike the preservation of Native American objects in museums, the point is to prevent loss and to have a material record of the odd and important things that define our culture and aesthetic sensibilities. 
However, Robinson is uncomfortable with the Council's proposed preservation easement of the Ford House. He has very meticulously done everything possible to maintain the Ford House, and he would like to see it remain intact - but this comes at a price. According to Robinson, the significance of the house is that it presents a range of personal interpretive choices - "what living can be, what unconventional can mean, what delight can include" not as a destination, part of a "collection of places to see in the great tourist industry," (2001:7), which is the ultimate conclusion of landmark status. Its value is in its "interpretive richness" rather than in any static qualities that can be traced back to the original owners or even the architect. This interpretive richness is not preserved through landmark status but risks being lost. The interpretive choices are narrowed by both the urgency of its materiality - its appearance and maintenance - and the limitations of cultural significance. In short, the house is put into "a situation where the potential for interpretive activity is diminished by a categorical decline in subtlety" (ibid.:8).

To make his point, Robinson relies on the story of the Crystal Palace, a building that was caught in a maelstrom of political, economic, and cultural interests in the mid-nineteenth century. The building was left to crumble and eventually burned to the ground in 1936. According to Robinson, the many and varied interpretations of the Crystal Palace "have given it a unique role in the history of architecture," interpretations that seem not to suffer from the loss of the building per se (2001:5-6). Implicit in Robinson's telling of the trials and tribulations of the Crystal Palace is the possibility that the disappearance of the structure has generated a richer commentary on the politics and culture at the time of its construction and subsequent disputes about its continued existence. When significant structures become part of the preservation and tourist industry, this richness in interpretation is potentially overshadowed by, or worse yet, simplified, and fixed as truths under the sheer weight of the materiality of the structure. Without disparaging the building itself, Robinson comments (2001:6) that the only clear loss in the destruction of the Crystal Palace was the disappearance of yet another tourist destination.

With respect to the Ford House, it is the personal interpretive process that is most worth preserving, not its cultural significance. The Ford House is a home and, as such, it is at the personal level where both the richness and range of interpretive choices are maximized and uniformity is minimized. It is here where the notion of culture as embedded in choices and creative processes rather than materiality is fostered, more or less (although of course never completely), unconstrained by the politics of cultural preservation. If the Ford House officially becomes cultural property through the imposition of a preservation easement, Robinson fears that much of the value of the structure, its ability to challenge and enrich our assumptions about living, will be lost under the checklist of significant features typically found in a tourist brochure.

C Blackwell Publishing Ltd. 2003 


\section{SUMMARY}

Both of these examples involve objects that began as something personal, intimate, or even spiritual. The cultural recognition of such things does not capture this significance but indeed obscures it. The status of being "cultural" property imposes a whole new set of constraints and ideas on the objects in question and while this may not necessarily be a bad thing, it would be a mistake to understand such status as indicative of authenticity. Not everything and perhaps not even the most cultural qualities are actually retained in cultural preservation. Indeed the increasing urgency of the cultural preservation movement tells us more about our cultural sensibilities than the objects upon which it focuses.

\section{THE NATURE OF CULTURAL OBJECTS}

In the following section, I explore what might be lost in our collective desire to preserve meaningful material objects and places. Robinson and Harkin focus on a loss in personal meaning and flexibility in interpretation - I refer to this as the intimate aspect of some things designated as cultural property. Their papers, however, along with the work of Richard Handler, point to other problems. First, the locus of meaning with respect to important objects is always shifting and indeed consistently builds on prior categorizations. Consequently, authenticity, the most prized goal of preservation, is forever elusive. Second, a focus on the materiality of cultural property obscures the politics behind the choices that go into preservation. The current prevailing understanding of the material culture becomes fixed by the object itself thus presenting itself as the definitive story rather than the outcome of a series of politically motivated choices.

\section{A. THE INTIMATE OBJECT}

The above examples seem odd, both in their pairing and in the peculiar, almost idiosyncratic, understanding of the objects in question. It would be easy to marginalize these examples as nothing more than exceptions. Indeed, we are generally comfortable with the tutelary, albeit constraining, role that cultural property plays in our lives (see Levinson 1998:199). ${ }^{10}$ We visit museums, galleries, and tourist sites to learn, not just in search of personal experience. The loss in subtlety that Robinson speaks of seems a small and inconsequential price to pay for a sense of security and permanence. In short, I will pay the price (if we could call it that) of experiencing cultural objects through the layered gauze of collective cultural interpretations, if only for the chance to experience them at all. Furthermore, there are, as stated at the outset, objects of cultural property, memorials, and the like, that do indeed seem better understood as repositories of changing public and collective meanings even if our interactions with them are personal. 
All that being said, these examples are not so odd. Aesthetic objects, relics, and collectible artifacts take on meaning primarily as abstractions of ourselves. Susan Stewart articulates this eloquently in her discussion of souvenirs. She states that within cultures defined by an exchange economy, saturated with fungible commodities, the search for something authentic and unchanging seemingly becomes critical but remains "both elusive and allusive as it is placed beyond the horizon of the present lived experience, the beyond in which the antique, the pastoral, the exotic, and other fictive domains are articulated" (Stewart 1993:133). While necessarily being the products of specific times and circumstances, collectible objects assume a certain transcendent quality, authenticating personal experience by distancing it from the self - simultaneously reaching back into time and creating a "utopian sense of anticipation" (Chow 2001:288) for what is to come. Harkin, citing Gadamer, refers to this "timeless" quality as "parousia, absolute presence," in which the object seems to draw us into its mythical status (Harkin 2001:9). Through ownership, what Walter Benjamin refers to as "the most intimate relationship that one can have to objects" individuals learn to live through and in this mythical status (Chow 2001:288). "Thus, while we may speak of mementoes, heirlooms, and souvenirs as significant in and of themselves containing memories and scents of things beyond the owner, their significance is more contingent on the self; it is the collector who lives through and shapes the meaning of the object.

So objects, whether aesthetically significant or mundane, do not have lives separate from our personal attachments. Their significance is both a product and reflection of the meaning we bestow. Such meanings are never entirely personal in that it is "impossible to avoid coming into contact with a system of evaluation that is external to and other than itself" (ibid.:298), but it also seems misguided to ignore the personal element. The personal is not only the site of multiple interpretive possibilities, as Robinson argues, but also that which is being rooted and authenticated. The elevation of objects above their obvious use-value is a longing for an intimate relationship; a relationship and existence that provides a sense of permanence and status above what is otherwise attainable. This desire is particularly evident in Western cultures and capitalist economies but this does not make the objects themselves "cultural." The preservation of objects is a mere manifestation of our cultural desire to conjoin materiality, permanence, and transcendence.

Our increasing obsession with preserving objects or things that we fear losing has some grounding in romanticism's construction of nature and its discovery of totemism. W. J. T. Mitchell notes that "Totemism is the figure of the longing for an intimate relationship with nature and the greeting of natural objects as friends and companions - the entire panoply of tutelary spirits from Wordsworth's daffodils to Coleridge's albatross to Shelley's west wind." Here "natural objects enter into a family romance with human consciousness" (2001:182). It should come as no surprise, given this description, that the cultural and environmental preservation movements share similar histories and philosophies. Both are at least partially grounded in the desire 
of the self to seek representation through external constructs and objects that seem both greater than and lesser than the self.

Cultural preservation policies share many of the same motivations and can be understood in much the same way as our desire to cherish souvenirs and personal memorabilia. Such policies reflect a collective expression of our individual desires for authentication. ${ }^{12}$ The privately maintained wonder cabinets of the renaissance are not far removed from the modern day public museum. ${ }^{13}$ Nonetheless, the official designation of an object or place as cultural property carries with it an assumption of collective meaning that, once identified, risks becoming static and removed from the experiences that generated significance.

Anthony Giddens comments that:

heritage is tradition repackaged as spectacle. The refurbished buildings at tourist sites may look splendid, and the refurbishment may even be authentic down to the last detail. But the heritage that is thereby protected is severed from the lifeblood of tradition, which is its connection with the experience of everyday

life. $(2000: 62)$

The "experience of everyday life" that Giddens speaks of is both dynamic and personal. Tradition, for all its collective sensibilities, must be played out, internalized, and reinterpreted through individual experience. The process of preservation, turning tradition into heritage, generates an official story often erasing or at least subverting alternative personal interpretations or more subtle understandings of the object. Cultural property categorically becomes collective where only the objects of our own individual fascinations - the products of everyday life - existed before.

The process of cultural recognition is also a process of further objectification. We might say that the personal recognition of objects draws us toward and involves us in the experiences they are meant to represent - an heirloom draws us back to memories of deceased family members, a souvenir generates thoughts of exotic destinations. Cultural recognition, on the other hand, tends to move us away from lived experience to the object itself. In this sense, officially recognized cultural property defines rather than represents lived experiences and risks generating an impersonal and inflexible representation of culture.

\section{B. THE DIALECTICAL OBJECT ${ }^{14}$}

Understanding the presence and significance of intimate connections in constructing the value of material culture is only one of the missing pieces in the legal comprehension of the nature of such objects. Another is an awareness of constantly shifting meanings. Here cultural preservation policies serve a dual function: they generate assumptions of unchanging continuous meaning while simultaneously affecting redefinition. Nowhere is this more evident than in the repatriation of potlatch artifacts to the Northwest Coast cultures. As Harkin notes, the categorization of Northwest Coast masks and ceremonial

(C) Blackwell Publishing Ltd. 2003 
objects as cultural property is itself a significant cultural innovation, reflecting the political and cultural aims of contemporary Kwakiutl society, or at least the younger generations within it. In another context, I have argued that repatriated Native American cultural property fluctuates in meaning and significance based on a host of factors, not the least of which is what the objects actually mean to non-Indian society and their status as valuable "cultural" commodities (Harding 2001). It is this shifting and reflexive or dialectical meaning of cultural objects that forms the focus of this section.

Richard Handler and Eric Gable's Work on Colonial Williamsburg, an active living piece of cultural property, also highlights this point (Handler \& Gable 1997). As the title of their book suggests, The New History in an Old Museum: Creating the Past at Colonial Williamsburg, Colonial Williamsburg, intended as an historically accurate replica of colonial American life, has indeed gone through a number of dramatic shifts in meaning, from the old history to the new. With each shift, the museum is reconceived, reoriented, and redesigned. And yet each shift, each representation is meant to be accurate, an authentic portrayal of colonial life. Handler and Gable quote a travel section article in which the writer notes, "For years, Colonial Williamsburg was burdened with a reputation ... as a too-cute, too-contrived, Disneyesque re-creation ... But that is precisely what it isn't... It is authenticity that the Colonial Williamsburg Foundation ... has sought...." and, according to this specific travel-writer achieved, right down to the pleasantly squishy "road apples" that ornament the road (Handler \& Gable 1997:6).

A similar and now well-known story has been told of the Scottish kilt. Contrary to standard assumptions and popular history, kilts did not emerge out of the mists of Scottish history but instead were a product of the industrial revolution and an enterprising English industrialist. Clan tartans were the creation of nineteenth century tailors attempting to create new markets. Only later did the kilt's close association with Scottish identity, more specifically the Highlander, serve to retrospectively construct its symbolic past (Trevor-Roper 1992).

The shifting meaning or "creative recontextualization" (Thomas 1991:5) of objects, apparent in all the stories, is above at the core of Nicholas Thomas' work on material culture and colonialism. He states:

One of the central ideas ... of this work is that objects are not what they were made to be but what they have become. This is to contradict a pervasive identification in museum research and material culture studies which stabilizes the identity of a thing in its fixed and founded material form. (Thomas 1991:4)

While this passage focuses on the "recontextualization" of objects originating in indigenous societies, Thomas' work is meant to highlight the appropriation and movement, in both directions, of objects under conditions of colonialism revealing an "entanglement ... grounded in local cultural and political agendas, rather than naïveté" (1991:88). The notion that "white commodities" were "irresistible" to native populations, their advantages immediately

C Blackwell Publishing Ltd. 2003 
apparent, assumes the "properties of artifacts and introduced items [was] self-evident." To the contrary, Thomas notes, the native reaction to "white commodities" was mixed. Items with seemingly obvious use value, such as axes, might be set aside and grouped with other things "specially devoted to the gods" (ibid.:87). In short "creative recontextualization" was pervasive and operated in both directions.

The problem here is that cultural preservation policies and laws have difficulty accommodating this "creative recontextualization." The legal protection or repatriation of cultural objects is compelling only under conditions of relative certainty about the meaning of an object. While the possibility of changing meaning is always implicit, cultural preservation policies sell themselves on assumptions about permanence - on the establishment of a definitive link between the past, present, and future. ${ }^{14}$ Repatriation legislation dependent on recognition of cultural significance would be short-lived if this link was weakened or broken and repatriated objects were put to completely inconsistent uses, neglected out of disinterest or sold back to private dealers. The expectation is that the meaning of the objects in question is static and true to "tradition."

So while constantly shifting meanings is an expected feature of anything we might label "cultural," preservation policies constructed around this label dwell on the presumption of unchanging interpretations. Cultural property laws are, in this sense, like intellectual property laws, at least as understood by Rosemary Coombe; they are an example of "the way in which authorities 'arrest the inherent semantic flux of discourse and ... impose a rigid code of equivalences between language and reality" (Coombe 1998:85). But official cultural preservation policies do more than give short shrift to the possibility of change. In addition, they gloss over the extent to which the policies themselves and the labels they impose generate new meanings or identities. As labels such as "cultural patrimony," "cultural property," and "cultural heritage" adhere to the objects they modify, the notion of a "dialectical object" begins to emerge. Cultural objects and the histories we associate with them aren't just the products of shifting meanings - the objects themselves along with the labels we attach to them partake in the creation of new identities or, as Mitchell has noted (2001:183), new temporalities that complicate one another.

This is evident in the changing status of Native American cultural objects. Returned artifacts do not simply slip back into their former pre-colonial identities. They are not just culturally significant objects, they are repatriated culturally significant artifacts. Michael Harkin states, "once artifacts have been transformed into . . 'objects of ethnography' any redefinition is highly unlikely" (2001:17). The fact they have been returned and what that tells us about the increasing bargaining power of Native Americans is as important as the objects themselves - repatriated cultural patrimony represents entitlement along side cultural renewal. It is this understanding of repatriated objects that seems to be driving the younger generation that Harkin speaks of. They 
comprehend the complex mix of political, economic, and cultural forces that are integral to the status of repatriated objects and have worked quickly to capitalize on it solely through an entitlement to cultural identity.

Viewed this way, repatriation is part of a larger political struggle for self-determination and sovereignty, not simply cultural renewal (Coombe 1998:238-39). The meaning of repatriated cultural objects has accordingly been shaped by that struggle and is a product of current needs and interpretations (Handler 1991:69). Indeed, the appropriation of the ideology of possessive individualism and its assumption of the connection between identity and property is itself part of this political struggle (see Handler 1991:67). In short, current expressions of indigenous culture through claims to cultural property can be understood as the intentional appropriation of Western and museum ideology. While the western European mindset often fails to see instances of counter-appropriation, expecting nothing but authentic traditional culture from indigenous peoples, it shouldn't come as a surprise. As Elizabeth Povinelli remarks: "Is it surprising, then, that the embodiment of 'culture' reflects variations, slippages, dispersions, and ambivalences of discursive and moral formations across the variegated terrain of indigenous and nonindigenous social life?"' (2002:3).

Thus the specific histories or biographies of cultural items including their checkered pasts, are never erased through renewal, rejuvenation, or repatriation (Kopytoff 1986) - all elements of preservation policies. Our current understandings of culturally significant objects and places are necessarily products of the prior status of such objects - repatriated objects are as much marketable pieces of art and ethnographic wonders as they are the spiritual entities they once were exclusively considered. A clear example of this outside of the repatriation context is the age factor found within historic preservation regulations. Under such regulations, the mere age of an object or place is a potential element of its significance and thus can elevate it to the status of "cultural" property (National Register of Historic Places 1981:36). ${ }^{16}$ In such circumstances the significance of the object or place is a product of its longevity as much as anything we might consider more intrinsic to the property itself. To return to the Ford House, the fact that it has survived more or less unaltered for over fifty years and that independent owners have found it worth preserving contributes as much to its significance as its odd construction.

How do these observations - that the cumulative history and shifting meanings of items of cultural property are central to its recognition as such - mesh with the seemingly contrary argument at the outset of this section - that cultural preservation legislation leads us to accept relatively fixed and generalized interpretations of cultural property? The problem is that while official cultural property status incorporates and, in some circumstances is even premised on recognition of the dialectic nature of the meaning of cultural objects, official cultural property status simultaneously risks watering down the rich stew of particulars associated with that dialectic. The concern is one that always accompanies legally recognized narratives, particularly those dealing with 
indigenous peoples: the dominant story, which is generally speaking the product of Western categories of meaning and evaluation, becomes the official story. In this fashion, the narratives of official cultural property risk becoming what Patricia Ewick and Susan Silbey refer to as hegemonic tales (1995:200). ${ }^{17}$ By constructing a "coherent whole, that is, the configuration of events and characters arranged in believable plots" preservation and repatriation policies risk "preempt[ing] alternative stories" and in doing so "coloniz[ing] the consciousness" (Ewick \& Silbey 1995:213).

Thus, the dialectic that emerges is again one that we can see connected to romanticism. Our collective conception of cultural property seems to fall within what Mitchell argues is the dialectical nature of the "romantic image": a "combination of fossilism and totemism, a dialectical figure of animation and petrification, a ruinous trace of catastrophe, and a 'vita' sign" (2001:184). While our worship of cultural objects can be conceptually linked to "totemism," the manifestation of this in the form of preservation "a petrified imprint, both icon and index, of a lost form of life" (ibid.:182) - is linked to "fossilism" The "fossil" in this case, as in the romantic image, turns out to be "the inevitable defeat" of our desire for transcendence, for an "intimate communion" with something beyond ourselves, something authentic (ibid.:183).

\section{THE POLITICAL OBJECT}

The problem is we don't think enough about the intimate origins or associations of cultural property or about its constant shifts in meaning. Our obsession with maintaining a concrete, material link to a certain past has led us to turn cultural preservation into a cultural lifeline and a communal obligation. Of course, the individual interpretive process continues but what is lost, in addition to the subtleties, is an acknowledgment of the centrality of this process to culture. We resign ourselves to the tutelary role the state assumes through cultural preservation policies. Perhaps of greater concern is that we also lose sight of the politics of cultural recognition - that the "category of cultural property is an instrument for exercising power: economic, cultural and political" (Robinson 2001:7). Museums are, as Handler and Gable write, "arenas for the significant convergence of political and cultural forces.... [not] simple repositories of cultural and historical treasures" (Handler \& Gable 1997:8). The politics that generate competing presentations in Colonial Williamsburg, disputes over a Saatchi exhibit, and repatriation policies are central to how we perceive and understand the items themselves. As Coombe recognizes, "ultimately, questions of culture and its appropriation are political rather than ontological ones" (1998:242).

All of the complexity and politics seem to disappear under the weight of the object and its cultural designation. The pure "thingness" of cultural property invites us to concretize and concentrate our understanding of what is cultural and what is not; "we imagine cultural traits as things" divorced from 
the political and economic forces that produce such recognition. In a student note on the battle over the preservation of Maxwell Street in Chicago, Mark Brookstein documents quite clearly the influence of city politics in determining what properties or districts are preserved (2001:1887). Maxwell Street was, like the Lower East Side in Manhattan (now a protected site, see Dewan 2001:A21), nothing much more than a collection of run-down buildings that nonetheless served as the gateway to Chicago for successive waves of immigrants. It is also considered the birthplace of Chicago-style blues. The Chicago Landmarks Commission, however, found that the district lacked "integrity" and rejected the recommendation of the Illinois Historic Preservation Agency that Maxwell Street be placed on the National Register of Historic Places. Records of the proceedings, however, indicate that the commission was equally, if not more, concerned about rejecting the expansion bid of the University of Illinois in Chicago. At one point in its deliberations, the Chicago Landmarks Commission stated "[e]ach position can be argued for and against, but the wisest course of action may be a carefully worded endorsement as long as it does not hinder UIC's ability to expand" (Brookstein 2001:1877). Whether one thinks this is a travesty of politics or a triumph of commonsense has little bearing on my analysis. My concern is that we are left with the conclusion that this has something to do with lack of cultural significance or "integrity" when such opinions are the mere by-products of a decision based on a set of political motivations.

The preservation of cultural property, understood as a political and cultural process, immediately draws parallels to the process of destruction. Whether we focus on Nazi policies regarding "degenerate art," the Taliban's destruction of Buddhas or standard book burning, what seems to drive these acts of destruction is no different from our compulsion to preserve. In both cases, the need for collective, politically generated meaning, for objective concrete symbols of culture, simultaneously serves to quash dissent. Both public preservation and public destruction make, although to different degrees, the same assumptions about the danger of rival interpretations (Chow 2001:289).

Anthropologists and social theorists, as Coombe and Handler note, have for quite some time understood that it is impossible to "conserve or authentically re-create culture ... [A]ll culture exists in the present, and must be enacted and re-enacted or interpreted and re-interpreted, in the present by human beings who are all in one way or another 'real' or 'authentic" (Coombe 1998:226). While cultural preservation policies need not contradict these important observations (indeed our obsession with preservation is itself an important cultural artifact) they come perilously close to tricking us into believing that authentic culture can be captured in material form. Our attention is diverted away from the choices we make and how they influence our lives to a set of material objects that efface those choices and thus resist contradiction. The material objects, in Coombe's words, "come to epitomize collective identity" (ibid.:224).

(C) Blackwell Publishing Ltd. 2003 


\section{LAW\& POLICY January 2003}

Perhaps all of this makes little difference when dealing with the cultural heritage of a dominant culture. The fact that Colonial Williamsburg may reconstruct itself and in doing so affect our knowledge of the past is less worrisome so long as we can continue to see the innovation at play and the centrality of this to any conception of the past. Conflicting narratives are likely to be more resilient when they emanate from within the dominant culture. We are quicker to comprehend at least the possibility of politics in the Maxwell Street decision or the element of spectacle in the construction of Colonial Williamsburg, over and above the official reliance on professionalism and technical standards. The process of recognition (or rejection) is likely to be more transparent when dealing with the familiar.

However, when preservation policies are enacted to deal with the cultural heritage of marginalized peoples, the potential for discontinuities in the construction and entrenchment of the cultural property category increase. I have argued elsewhere that such legislation is a good thing and no doubt serves a variety of intended and unintended purposes - political, economic, and cultural (Harding 1997). I still believe this to be the case. At the very least, principles of fairness require a commitment to repatriation. The above analysis should nonetheless affect how we construct standards for defining the cultural heritage of indigenous peoples. The terms and categories constructed should be flexible enough to allow for the development of continuities in interpretation rather than effacing such continuities.

The definition of "cultural patrimony" under NAGPRA is flexible in that Native American communities themselves determine what items fall within this category. But such decisions are nonetheless bounded by terms dictated by the constraints of the dominant legal system as well as essentialist perceptions of Indian culture. For example, only those items legitimately classified as belonging to the group as a whole and considered to be inalienable count as cultural patrimony. These requirements reflect an expectation of otherness - a culture unaffected by markets and the allure of private property - while simultaneously articulating the impossibility of a legitimate transfer outside the tribe. Only the status of group ownership and inalienability is enough to taint subsequent museum ownership and, thus, provide a legitimate basis for return.

These constraints have led to changes in the meaning of objects that while clearly unique and vital to the particular culture might not otherwise satisfy the definition. This is precisely the problem that Harkin highlights (2001). My point is not to reject these repatriations but rather to point out they reflect innovations necessitated by or at least stemming from the terms in the legislation itself. While such innovations are inevitable, we still need to be cognizant of the importance of constructing legislative definitions of cultural property that create space for the existence of multiple narratives rather than privileging one over another. We need to resist our tendency to insist "that aboriginal peoples must represent a fully coherent position that expresses an authentic identity forged from an uncomplicated past" (Coombe 1998:243). 


\section{CONCLUSION}

In his discussion of lyric poetry and "the material substance of things," Daniel Tiffany urges us to "abandon uncritical assumptions about the nature of material substance. ... [T] he reality of matter must always remain uncertain, always a problem that needs to be taken into consideration" (1999:97). Lawmakers dependent on at least the appearance of certainty and definition exist far from Tiffany's world of literary criticism, but there is value in this prescriptive message. While I am not prepared to argue against cultural preservation legislation and its privileging of definitive interpretations of material culture, I do think it is important to be cautious about sweeping too much or bestowing too much meaning into the cultural property category and its standards of recognition. The problem, of course, is that cultural property laws are "written in terms of an objective, not semiotic, conception of culture" (Handler 2003:16). While it seems impossible even to imagine that this could change, this limitation should, at the very least, urge us to be cautious about the process of preservation, what we expect to achieve through cultural preservation policies and the effects of such policies on our conception of culture.

SARAH HARDING is an associate professor at Chicago-Kent College of Law, and is a research fellow at the Research School of Social Sciences, Australian National University (2002-2003). Her research interests include cultural property, the philosophical foundations of property law, and comparative constitutionalism.

\section{NOTES}

1. Implementing the 1970 UNESCO Convention on the Means of Prohibiting and Preventing the Illicit Import, Export and Transfer of Ownership of Cultural Property.

2. Legislation protecting the heritage of indigenous peoples typically contains repatriation provisions that in effect bring about a change in ownership as the objects move from museums back into culturally affiliated communities (e.g., NAGPRA 1990).

3. A good example of this is Penn Central Transportation Co. v. City of New York 1978 in which the New York City Landmarks Preservation Commission successfully prevented the owner of Grand Central Station from proceeding with plans to constract an office tower above the historic Station.

4. The Jonaitis collection was published as a guide to a major exhibition also entitled "Chiefly Feasts" at the American Museum of Natural History (1991).

5. Detailing the past and future plans for repatriations.

6. Clifford (1997) writes about two Native museums on the Northwest Coast, noting that the display at the U'Mista Cultural Center in Alert Bay focuses on political-historical representations whereas the Kwagiulth museum in Cape Mudge emphasizes the aesthetics of individual objects and family connections. These two museums were made possible through repatriation of the "potlatch collection" in 1979.

7. The Bruce Goff Archives are held at the Art Institute of Chicago. 


\section{LAW \& POLICY January 2003}

8. A preservation easement would be one of many preservation options and the least restricting of them. Placing the house on the National Register of Historic Places would, according to Robinson, further overshadow the interpretive possibilities.

9. For general information regarding preservation procedures, see the Landmarks Preservation Council of Illinois Web site available at http://www.landmarks.org. Particular information on the preservation easement is available at http:// www.landmarks.org/about_lpci_copy.htm.

10. Commenting that "states privilege certain understandings of the community, and thus inevitably disadvantage alternative understandings" (Levinson 1998:199).

11. Quoting Walter Benjamin, "Unpacking My Library: A Talk About Book Collecting."

12. A further inevitability may be the transformation of entire ways of life into spectacles - "from production to consumption." Susan Stewart remarks:

We see this same transformation from industrial production to the spectacle over and over again in the current crisis of late capitalism. Flint, Michigan, for example, recently announced that it would solve its Depression-level unemployment problem by creating an Auto-World, a Disneyland of the automobile industry which is expected to draw tourists from all parts of the globe. (Stewart 1993:145)

13. For an interesting discussion of the continuities, as well as discontinuities between the wonder cabinet and modern museums, see Greenblatt (1991:50-51).

14. Although he used it in a different context, the idea of a "dialectical object" comes from W. J. T. Mitchell (2001:180).

15. This problem is one that is a natural extension of the temporalities of law itself. As anthropologist Carol Greenhouse has observed, the law tends to be both unchanging and dynamic (Greenhouse 1989).

16. Included are all the requirements for listing on the National Register of Historic Places.

17. A similar argument is made by Coombe, again in the context of intellectual property protections. She states: "Laws of intellectual property privilege monologic forms against dialogic practice and create significant power differentials between social actors engaged in hegemonic struggle" (1998:86).

\section{REFERENCES}

AMERICAN LAW INSTITUTE - AMERICAN BAR ASSOCIATION (ALI-ABI) (2001) "Model Historic Preservation Easement," National Trust for Historic Preservation. Philadelphia, Pennsylvania: ALI-ABA Committee on Continuing Education.

ARJUn, APPADURAI (ed.) (1986) The Social Life of Things: Commodities in Cultural Perspective. Cambridge: Harvard Univ. Press.

BROOKSTEIN, MARK (2001) "When History is History: Maxwell Street, 'Integrity' and the Failure of Historic Preservation Law." Chicago-Kent Law Review 76:1847-86.

CANAdian MUSEUM OF CIVILIZATION (2001-2002) Summary of the Corporate Plan, 19961997 to 2000-2001. Available at www.civilization.ca.

CHOW, REY (2001) "Fateful Attachments: On Collecting, Fidelity, and Lao She," Critical Inquiry 28:286-304.

CLIFFORD, JAMES (1997) Routes: Travel and Translation in the Law Twentieth Century. Cambridge, Mass.: Harvard Univ. Press.

COLE, DOUGLas (1985) Captured Heritage: The Scramble for Northwest Coast Artifacts. Vancouver: Douglas \& McIntyre.

COOMBE ROSEMARy (1998) The Cultural Life of Intellectual Properties: Authorship, Appropriation, and the Law. Durham: Duke Univ. Press. 
DAES, ERICA-IRENE (1993) Study on the Protection of the Cultural and Intellectual Property of Indigenous Peoples, UN Doc. E/CN.4/Sub.2/1993/28 (1993).

DE LONG, DAVID G. (1988) Bruce Goff: Toward Absolute Architecture. Cambridge, Mass. Boston: MIT Press.

DEWAN, SHEILA (2001) "Lower East Side is Added to U.S. Register of Historic Places," New York Times 18 April:A-21.

EWICK, PATRICIA, and SUSAN SILBEY (1995) "Subversive Stories and Hegemonic Tales: Towards a Sociology of Narrative," Law \& Society 29:197-220.

GIDDENS, ANTHONY (2000) Runaway World: How Globalization is Reshaping Our Lives. New York: Routledge.

GREENBLATT, STEPHEN (1991) "Resonance and Wonder." In Exhibiting Cultures: The Poetics and Politics of Museum Display, edited by I. Karp \& S. D. Lavine. Washington, D.C.: Smithsonian Institution Press.

GREenHouse, CAROL (1989) "Just in Time: Temporality and the Cultural Legitimation of Law," Yale Law Journal 98:1631-51.

HANDlER, RICHARD (1991) "Who Owns the Past? History, Cultural Property and the Logic of Possessive Individualism." In The Politics of Culture, edited by B. Williams. Washington, D.C.: Smithsonian Institution Press.

HANDLER, RICHARD, and ERIC GABLE (1997) The New History in an Old Museum: Creating the Past at Colonial Williamsburg. Durham: Duke Univ. Press.

HANDLER, RICHARD (forthcomg 2003) "Cultural Property, Culture Theory," Journal of Social Archaeology 3.

HARDING, SARAH (1997) "Justifying Repatriation of Native American Cultural Property," Indiana Law Journal 72:723-74.

HARDING, SARAH (1999) "Value, Obligation and Cultural Heritage," Arizona State Lav Journal 31:291-354.

HARDING, SARAH (2001) "Culture, Commodification and Native American Cultural Patrimony." Paper presented at Commodification Futures, University of Denver School of Law, 30-31 March, Denver, CO.

HARKIN, MICHAEL (1999) "From Totems to Derrida: Postmodernism and Northwest Coast Ethnology," Ethnohistory 46:817-30.

HARKIN, MICHAEL (2001) "Privacy, Ownership and the Repatriation of Cultural Properties: An Ethnographic Perspective from the Northwest Coast." Paper presented at Categories, Culture and Property, Chicago-Kent College of Law, 28 September, Chicago.

Jonaitis, Aldona (ed.) (1991) Chiefy Feasts: The Enduring Kwakiutl Potlach. Seattle: Univ. of Washington Press.

KOPYTOFF, IGOR (1986) "The Cultural Biography of Things: Commoditization as Process." In The Social Life of Things: Commodities in Cultural Perspective, edited by A. Appadurai. Cambridge, Mass.: Cambridge Univ. Press.

LEVINSON, SANFORD (1998) "The Tutelary State." In Censorship and Silencing: Practices of Cultural Regulation, edited by R. Post. Los Angeles: Getty Research Institute.

MITCHELl, W. J. T. (2001) "Romanticism and the Life of Things, Fossils, Totems, and Images," Critical Inquiry 28:167-184.

POVINELLI, ELIZABETH (2002) The Cunning of Recognition: Indigenous Alterities and the Making of Australian Multiculturalism. Durham: Duke Univ. Press.

ROBINSON, SIDNEY (2001) "Reflections on Living in a Cultural Property." Paper presented at Categories, Culture and Property, Chicago-Kent College of Law, 28 September, Chicago.

Saliga, PaUline, and Mary wOOLEVER (1997) The Architecture of Bruce Goff, 19041982: Design for the Continuous Present. New York: Prestel Publishing.

STEWART, SUSAN (1993) On Longing: Narratives of the Miniature, the Gigantic, the Souvenir, the Collection. Durham, N.C.: Duke Univ. Press. 
THOMAS, NiChOLAS (1991) Entangled Objects: Exchange, Material Culture, and Colonialism in the Pacific. Cambridge, Mass.: Harvard Univ. Press.

TIFFANY, DANiEL (2001) "Lyric Substance: On Riddles, Materialism, and Poetic Obscurity," Critical Inquiry 28:72-98.

TREVOR-ROPER, HUGH (1983) "The Invention of Tradition: The Highland Tradition of Scotland." In The Invention of Tradition, edited by E. Hobsbawm \& T. Ranger. New York: Cambridge Univ. Press.

\section{CASES CITED}

Penn Central Transportation Company v City of New York, 438 U.S. 104 (1978).

\section{LAWS CITED}

Australia

Aboriginal and Torres Strait Islanders Heritage Protection Act (1984).

Protection of Moveable Cultural Heritage Act (1986).

Canada

An Act to Further Amend the "Indian Act, 1880" Statutes of Canada, (SC), c 27 (1884).

United States of America

Chicago, Il, Municipal Code \$2-120-620 (1987).

Native American Graves Protection and Repatriation Act of 1990 (NAGPRA), 25 U.S.C. $\$ \S 3001-3013$.

National Register of Historic Places, 46 Fed Reg 56183 CFR 60.4 (1981).

Pre-Columbian Monumental and Architectural Sculpture and Murals Statute, Pub L No 92-587 (1972).

\section{INTERNATIONAL INSTRUMENTS}

Convention on Cultural Property Implementation Act, Pub L No 97-446, 96 Stat 2351 L 1987.

Convention on the Means of Prohibiting and Preventing the Illicit Import, Export and Transfer of Ownership of Cultural Property, 14 November 1970, 823 UNTS 231.

Convention for the Protection of Cultural Property in the Event of Armed Conflict, 14 May 1954, 249 UNTS 215.

UNIDROIT Convention on Stolen or Illegally Exported Cultural Objects, 34 ILM 1322 (1995). 